\title{
ACCOUNTING CHAMBER - THE LEADING INSTITUTION \\ IN THE FINANCIAL AND CONTROL ACTIVITY OF THE STATE
}

Koicheva O. S.

\section{INTRODUCTION}

There is a generally accepted global tendency to determine the welfare of the country, taking into account the indicators of social, economic development, GDP, which are caused by strategically correct decisions in the political and economic spheres. One of the ways to determine the effectiveness and efficiency of decisions is control activities, which are usually carried out by public authorities. State control, given the specifics of its subject, is quite extensive and is the competence of many bodies and institutions.

The banal postulate of the dependence of welfare on financial resources in the management activity of the state does not lose its relevance. Particular attention needs to be paid to the study of control activities directly in the financial sphere, which is one of the pillars of the welfare of the state.

Financial control is an indicator of the effectiveness of fiscal policy in the state, since ensuring the functioning of any sphere of the state life-sustaining activity requires funding from it. A high level of legality and discipline in the formation, distribution and use of public money funds is one of the criteria of the state of law. The effectiveness of financial control largely depends on the coherence of the system of bodies through which it is implemented, the functioning of each element of which is determined by objective needs. The existence and functioning of such bodies is a mandatory element of managing public financial resources, a condition for building a state of law, since the State budget, which is formed by taxpayers, establishes the financial basis for the existence of a state-organized society. These factors determine the keen interest of the scientific community and the public in bodies that exercise financial control. A financial control system is necessary, first of all, to prevent misuse of budget funds, fraud and corruption.

The problem of creating a unified system of financial control in Ukraine has been discussed among scientists and legislators for a long time. Financial control is central to the control system, so its effectiveness will depend on the future well-being of the state. The construction of an effective system of financial control bodies must first of all be set by the regulations. Scholars have repeatedly 
made proposals to work out a concept for the development of financial control, there was developed a draft law «On the system of public financial control in Ukraine», but all initiatives remained only at the level of wishes.

One of the most important bodies of financial control is the Accounting Chamber, which is recognized globally and internationally as the highest financial control body in Ukraine, thanks to membership in INTOSAI and EUROSAI. Over the years of its existence, this institution has significantly raised its prestige, which has earned professionalism and quality of work performed. It is unfortunate to realize that only a small part of the capacity of this body is used, which is caused by legislative irregularities. Determination of its place in the system of public financial control should be the earnest of high-quality and effective reform of the Accounting Chamber.

\section{Financial control - a kind of state control}

The current situation of the domestic system of state management, in accordance with the terms of the Association Agreement between Ukraine and the EU, encourages the search for new and effective approaches that will help regulate management relations on the basis of the acquis communautaire - the property of society ${ }^{1}$. Achieving this goal is possible with the use of modern methods and tools of public management, which will further develop and support global trends that have proven effective in managing public institutions, supporting and developing progressive social trends and ensuring the proper functioning of these institutions. The key to sustainable development of modern society can be extremely effective state management. Its effectiveness is ensured by various means, among which an important place is occupied by the control function.

The primary task to be solved to ensure state management reform is to determine the place and role of public control activities, the effectiveness of which must meet clear criteria, due to its practical significance.

There is no unanimity of opinion among scholars in the field of public administration and administrative law regarding the concept of control activity and its components.

O. Andriyko notes that state control is a function of management, which in the necessary ratio exists with others, and therefore control in the field of management has both independent significance and is an element of other management functions, a means of verifying the implementation of

1 Угода про асоціацію між Україною, з однієї сторони, та Європейським Союзом, Свропейським співтовариством з атомної енергії і їхніми державами-членами, з іншої сторони: Міжнародний документ від 27.06.2014 p. URL: https://zakon.rada.gov.ua/laws/show/984_011\#Text. 
management functions ${ }^{2}$. From the above-mentioned it can be concluded that the control activity has a dual legal nature - on the one hand - it is an independent function of state (public) government, on the other - an integral determining element of other functions.

The constellation of scientists supports the view that control activities, being a function of management, its stage and form, should still receive a higher status, for example, to form an independent control branch of government. Among the supporters of this point of view is V. Taroyeva ${ }^{3}$, who emphasizes the constitutional non-consolidation of control power in Ukraine. The bodies that exercise control powers are scattered in the branches of government, and this is not entirely appropriate, given the fact that state control is an important task of public administration and at the same time has a clear organizational structure. Based on the abovementioned, the researcher proposes to formalize the existence of a control branch of government at the legislative level.

It is difficult to agree with this opinion, because the consolidation of control activities at the constitutional level of a particular branch of government will unlikely solve the existing problems in this area of a practical nature. Confirmation of this is the pan-European trend to narrow the control powers of state institutions and expand the activities of public organizations, state corporations and more. Perhaps it is more appropriate to pay attention to the development of a unified approach to the terminological framework for the definition of control activities and the consolidation of the relevant conceptual apparatus at the legislative level.

The specialized and reference literature presents different approaches to the interpretation of the concept of «control». The very term «control» (from the French. Controle) means inspection or observation with the aim to verify. At the same time, the French controle (count + role) was formed from the Latin prefix contra, which means counteraction, and the word role, which means performing an action. Thus, the word «control», in addition to the meaning of inspection, supervision for the purpose of inspection, in its meaning also contains the concept of counteracting something undesirable. In this context, the term «control» should be considered as a check, as well as an observation for the purpose of checking to counteract something undesirable, to detect, prevent and stop illegal conduct. Hence, the term «control» reflects:

\footnotetext{
2 Андрійко О.Ф. Організаційно-правові проблеми державного контролю у сфері виконавчої влади: автореф. дис. ... д-ра юрид. наук. Київ: І-т. держави і права ім. В.М. Корецького НАН України, 1999. 38 с.

3 Тароєва В.В. Інститути контрольної влади в сучасній Україні: автореф. дис. ... канд. юрид. наук. Одеса, 2010. 21 с.
} 
a) particular activities; b) subjects of the particular activities. However, in the legal literature, control is defined mostly as a specific activity. And its important task, along with bringing to justice for offenses, is to prevent future offenses and encourage all stakeholders to conduct within the legal field ${ }^{4}$.

O. Andriyko focuses attention on the fact that state control can be general or special, distinguishing such a type of special state control as financial ${ }^{5}$.

The close connection between administrative and financial law in the field of financial control research is caused by at least two factors: 1) financial control is often considered as a control function of finance; 2) financial control is considered as a kind of state control.

The constellation of eminent scholars who have devoted their research to financial control can be divided into several groups depending on their understanding of financial control as a function, activity, type of state control, or a set of activities carried out by regulatory authorities.

The first group consists of supporters of considering financial control as a function. D. Bahrah emphasizes that control is an attribute of administrative power, one of its most important functions. It contains observations on the legality and expediency of activities, its assessment from a legal, scientific, socio-political, organizational and technical standpoint. In many cases, in order to ensure the freedom of citizens, enterprises, organizations, protection from excessive state guardianship, the control powers of the subjects of power are limited by legal acts, giving them the opportunity to exercise only supervision. And when there is no organizational subordination between the auditor and the audited entity, the separation of control from supervision is necessary to prevent interference in the operational activities of entities that are not responsible for its consequences. Supervision - it is a limited, narrowed control ${ }^{6}$. The author considers control in general, and gives his definition, which we need for further study of financial control.

The second group includes supporters of financial control due to certain activities necessary for its implementation. According to O. Kozyrin, «financial control should be understood as the activity of state bodies, and in some cases non-state bodies endowed with the relevant powers by law, carried out with the use of specific organizational norms and methods, in order to establish legality and reliability of financial transactions, objective

${ }^{4}$ I. Павлик. Відмінність понять «державний контроль» і «державний нагляд»: нормативноправовий аспект. Науковий віник. 2017. Вип. 20. URL: http://lvivacademy.com/vidavnitstvo_1/ visnyk20/fail/Pavlyk.pdf.

5 О. Андрійко. Зазначена праця.

${ }_{6}^{6}$ Административное право Украины: учебник / Под общей ред. С.В. Кивалова. Харків: «Одиссей», 2004. 880 с. 
assessment of the economic efficiency of financial and economic activities, identification of reserves for its increase, increase of revenue to the budget and preservation of state property» ${ }^{7}$.

Representatives of the third group consider financial control as a kind of state, carried out, respectively, by public authorities. An outstanding economist prof. B. Boldyrev in his textbook «Finance of capitalist countries» interprets financial control «as a form of state control over the formation, distribution and use of resources of all parts of the financial system ${ }^{8}$. O. Grachova and E. Sokolova note that financial control is a type of state control aimed at verifying the expenditure of public funds, timeliness and completeness of mobilization of state resources, legality of expenditures and revenues of all links of the financial system, compliance with accounting and reporting rules ${ }^{9}$.

S. Shokhin defines financial control in accordance with the financial law, which is a system of bodies and measures to verify the legality and appropriateness of actions in the field of formation, distribution and use of funds of the state and local governments, one of the forms of state control that promotes legality, protection of property, correct, efficient and economical use of budget, loan and own funds, which helps to elicit violations of financial discipline ${ }^{10}$.

For further study of the Accounting Chamber as an institution in the financial control activities of the state, we believe it is appropriate to proceed from the definition of financial control as a special institution of financial law, the rules of which are included in both general and special part. Financial control exercised by the Accounting Chamber is an activity in the performance of tasks assigned by the Constitution and is aimed at compliance with the rule of law and financial discipline in order to ensure the statutory revenues to the state budget and their effective use.

\section{The place of the Accounting Chamber in the system of financial control bodies}

Financial control from the direction of the state has a significant impact on all finances, which necessitates the interaction of all control and financial

\footnotetext{
${ }^{7}$ Козырин А.Н. Финансовый контроль. Финансовое право. Москва: Юристъ, 1996. 399 с.

${ }^{8}$ Болдырев Ю. Формирование внешнего государственного финансового контроля в РФ: вопросы истории, организации и методологии. Российский экономический журнал. 2007. № 5-6. С. 25-41.

${ }^{9}$ Грачева Е.Ю. Налоговое право: вопросы и ответы: учебное пособие / Грачева Е.Ю., Соколова Э.Д. Москва: Юриспруденция, 2001. 128 с.

10 Шохин С.О., Воронина Л.И. Бюджетно-финансовый контроль и аудит. Теория и практика применения в России: науч.-метод. пособие. Москав: Финансы и статистика, 1997. 240 с.
} 
bodies. The national control system is in the process of formation, but this does not indicate the creation of new control structures, but aims to improve the system of existing bodies, defining their competence, powers and place in it. Building an effective system of financial control bodies should, above all, be enshrined in law and meet today's challenges. The competence of the Accounting Chamber occupies a special place in the system of financial control bodies, which is due to the consolidation at the constitutional level of its special status.

Today, the institute of public financial control practically does not perform its main preventive function, acting, as a rule, only as a registrar of violations. Forms of subsequent control (audit and verification), which are mainly carried out by the state financial control, without supporting the audit of efficiency, almost lose their relevance and effectiveness in a market economy of Ukraine. Using these forms, it is impossible, for example, to check the quality of work performed and services, the quality of materials purchased with public funds, the efficiency of public resources, and so on. Therefore, it is too early to say that Ukraine has an integrated system of public financial control, let alone talk about its effectiveness. The organization and functioning of an effective system of public financial control is a mandatory element of public administration, and therefore financial control should not be carried out autonomously, but as an important link in the overall system of public administration. Thus, public financial control as the most important means of public administration is both a criterion for determining the effectiveness of this management.

Defining the system of financial control M. Gorbach provides for the definition of the following components: the totality of all bodies of this control; the relationship between them and public authorities; establishing a hierarchy of control bodies with the definition of a single body that is higher in the system of bodies of state financial control; identification of controlled entities; a list of tools (forms, methods, techniques, etc.) that can be used by specific control subjects; rights, duties, responsibilities of controlling and controlled entities and many other integral components of control ${ }^{11}$. The presence of financial control bodies in our country must be considered as a system, it is impossible to consider each body as a separate, unique element of this system. So far, the concept of «the system of financial control bodies», «public finance», «public financial control» has not been defined at the legislative level. Practical functioning is effective only under the condition of perfect normative

${ }^{11}$ Горбач М. Про створення єдиної системи державного фінансового контролю в Україні. Право Украӥни. 2005. № 10. С. 83-86. 
consolidation, which we, unfortunately, do not have. Former Chairman of the Accounting Chamber V.K. Symonenko noted that despite the fact that Ukraine is a rich country, public funds are used extremely inefficiently. He sees the reason for this in the lack of coherence and interaction between those bodies that are called to exercise financial control ${ }^{12}$. The inconsistency of actions of control and financial bodies leads to the fact that during the reporting period some institutions are subject to repeated inspections, and others are not inspected at all - this situation leads to negative consequences for the economy. Time is running out, and the situation in our country is only getting worse and requires urgent reforms in this area.

Bodies carrying out financial activities of the state, L.A. Savchenko divides into two groups. The first group should include those who directly exercise financial control and controlling subjects. Subjects exercising financial control include the Verkhovna Rada of Ukraine, the President of Ukraine, the Cabinet of Ministers of Ukraine, the Ministry of Finance of Ukraine, the Verkhovna Rada of the Autonomous Republic of Crimea and other state bodies, local self-governments, which, among other functions, have control powers. For these subjects, the control function in the financial sphere is secondary. The controlling subjects include: the Accounting Chamber, bodies of the State Tax Service of Ukraine, the National Bank of Ukraine, the State Customs Service of Ukraine, the State Treasury of Ukraine, the State Control and Audit Service of Ukraine, the Audit Chamber of Ukraine, the State Committee for Financial Monitoring, other state bodies, non-state organizations, independent auditors, as well as relevant services of enterprises, institutions, organizations, the main function of which is the implementation of financial control ${ }^{13}$.

I.Ye. Krynytskyi singles out his own criteria for classifying financial control bodies. 1) The level - national bodies (the Verkhovna Rada of Ukraine, the President of Ukraine, the Cabinet of Ministers of Ukraine, the National Bank of Ukraine, the Ministry of Finance of Ukraine, etc.); local self-governments. 2) The institutes (or institutions) - bodies exercising control in the tax and customs spheres; financial inspection (control and audit) bodies; bodies of the state treasury service; financial and credit (banking) institutions; currency control authorities; financial and monitoring bodies and others. 4) The competence - general competence (for which

\footnotetext{
12 Симоненко В.К. Бюджет без контролю - держава без бюджету. Демократична Украӥна. 2002. № 4. C. 4.

13 Савченко Л.А. Правові основи фінансового контролю: навч. посіб. Київ: Юрінком Інтер, 2008. 504 c.
} 
the implementation of financial control is not the main activity, such as the Verkhovna Rada of Ukraine, the Cabinet of Ministers of Ukraine); special competence (created exclusively or mainly for activities in the field of financial control, the most striking examples are the State Financial Inspection of Ukraine and the Accounting Chamber of Ukraine) ${ }^{14}$. Many scholars, considering the lack of a well-organized system of financial control bodies, do not classify bodies due to the lack of definition at the regulatory level of basic concepts - «single system of financial control», «public finance», «public financial control», «financial system» and so on.

Financial control can be effective and objective only when the subject of control is organizationally an external structure in relation to the controlled object, and in the hierarchy of subordination is higher than the object. Financial control bodies should be given real powers to influence the activities of the controlled object, there should be a clear order and procedure for making decisions based on the results of control.

Ukraine is a follower of the classical division of power into three branches, two of which - the legislative and executive have in their structure the bodies empowered to exercise state financial control. Many experts with regard to parliamentary control use the definitions of «external» and «independent». This approach is caused due to the presence of two equal parts of public financial: internal (government) state control (the Ministry of Finance, the State Audit Service, the State Treasury, the State Tax Service) and external - independent state financial control and public audit (the Accounting Chamber). Assignment of the powers of the external financial control body to the Accounting Chamber is conditional it exercises external control over the executive authorities, which cannot be said about the control over the Verkhovna Rada of Ukraine and its staff. The Accounting Chamber is a permanent control body formed by the Verkhovna Rada of Ukraine, subordinated to and accountable to it.

Regarding the classification of public financial control bodies, it can be noted that it is absent, which is caused by many criteria that may be the basis for classification, but the bodies exercising this control remain the same. Virtually every state body that has state funds at its disposal controls their efficient and targeted spending, but we are interested in bodies that control other objects.

Powers of general competence bodies (the Verkhovna Rada of Ukraine, the Cabinet of Ministers of Ukraine, the President of Ukraine, the

14 Фінансове право України: підручник / М.П. Кучерявенко, Д.О. Білінський, О.О. Дмитрик та ін..; за ред. д-ра юрид. наук, проф. М.П. Кучерявенка. Харків: Право, 2013. 400 с. 
National Bank of Ukraine) as a rule are exercised during the adoption and implementation of the Law of Ukraine on State Budget and are enshrined at the constitutional level, while specified at the level of special laws.

The system of public financial control, of course, should include only bodies of special competence, whose main activity is related to the implementation of financial control, which will be a criterion for grouping. The bodies that directly control the process of receipt of funds in the state budget and their use are: the Accounting Chamber, the State Treasury Service, the State Audit Service and the State Tax Service. These bodies should constitute a system of public financial control, the activities of which should be carried out on the basis of internal independence with general coordination within the system of public financial control.

At the legislative level, the status of the supreme body of financial control (hereinafter SAI) in our country is not assigned to anybody. Analysis of Art. 98 of the Constitution of Ukraine and the Law of Ukraine «On the Accounting Chamber» makes it possible to conclude that although the Accounting Chamber is not legally defined as an SAI, in fact it performs its functions. The Accounting Chamber has been a member of the International Organization of Supreme Audit Institutions (INTOSAI) since 1998, and a member of the European Organization of Supreme Audit Institutions (EUROSAI) since 1999. Thus, since 1998, the Accounting Chamber has been recognized by the international community as an SAI in Ukraine and has been cooperating in this area. The main international document in the field of public financial control - The Lima Declaration of Guidelines on Auditing Precepts in Art. 3 determines the division of financial control bodies into external and internal. In particular, external control bodies are not part of the organizational structure of the bodies under their control. That is why the highest bodies of control of public finances are the bodies of external control. The task of the SAI as an external controller is to verify the effectiveness of internal control. International Standards clearly regulate the SAI's activities and its interaction with internal financial control bodies. Fragmentary provisions of the standards are reflected in the Law of Ukraine «On the Accounting Chamber».

Having analyzed the public authorities endowed with powers in the field of public financial control, there is a need to adopt a normative act that would clearly define all aspects of the system of these bodies. In order to achieve results, the bodies of general and special competence, internal and external control must interact with each other and each of them must have clear limits on the exercise of their powers. Analysis of the status and 
powers of the Accounting Chamber shows that it is not just the highest subordination, but really the leading body of public financial control in Ukraine, which meets international standards, which is not insignificant, given the course of European integration. It is clear that it can take a leading role in the system of public financial control. The tasks of the Accounting Chamber should include the organization and coordination of the activities of all financial control bodies. The problem of coordination of interaction of the bodies that make up the financial system of Ukraine, the lack of its normative consolidation makes us hope only for the desire and willingness of officials to cooperate.

\section{Competence and powers of the Accounting Chamber}

In order to study the constitutional and legal status of the Accounting Chamber as a body of financial control, it is necessary to pay attention to the norms that establish its competence, as well as the specific powers that are represented by a set of rights and responsibilities. According to Art. 98 of the Constitution of Ukraine, the Accounting Chamber exercises control on behalf of the Verkhovna Rada of Ukraine over the receipt of funds in the state budget of Ukraine and their use. The relevant law regulates the powers granted and outlines the range of additional powers that contribute to the control activities of the body under investigation. St. 7 of the Law of Ukraine «On the Accounting Chamber» contains a list of powers, in order to analyze their implementation it is necessary to determine the competence of the SAI. To achieve this goal it is necessary to turn to the theoretical definition of such categories as «competence» and «authority».

The Accounting Chamber, as a body with constitutional status, has all the features of state bodies. When we talk about the competence of anybody usually means the set of elements of which it consists.

The legal encyclopedia defines the concept of competence (Latin competentia - responsibility, coherence, from competere - to mutually seek, respond, approach) as a set of established in the official (legal or non-legal) form of rights and responsibilities, i.e. the powers of any body or official persons who determine the ability of this body or official to make binding decisions, organize and monitor their implementation, take responsibility if necessary, etc ${ }^{15}$.

Noteworthy is the opinion of A.O. Tkachenko, who considers the functions as part of the competence of the body, examining how to answer

${ }^{15}$ Юридична енциклопедія: В 6 т. / Редкол.: Ю.С. Шемшученко (відп. ред.) та ін. Київ: «Укр. енцикл.», 2001. Т. 3: К-М., 792 с. 
the question of what does this body do. Functions in conjunction with powers constitute the competence of the body within which it operates. The author considers functions and powers as elements of competence in a broad sense, and by competence in a narrow sense it is meant only the rights and legal obligations of the body that constitute its powers. And the both concepts are defined as legal ${ }^{16}$.

Despite the large number of definitions of competence, the opinion of most scholars is that this definition has a two-member structure - the subjects of competence and authority (rights and responsibilities). There is no consensus on what is meant by these subjects of knowledge. For some, it is an area of public relations in which a public body operates, or where it is legally competent, or a system of public relations, which is influenced by the authorities or the sphere of their state leadership.

The powers of a state body are its «legal obligations», because in the presence of the necessary legal facts, the body can not fail to exercise its powers, acting as a holder of subjective rights in relation to the subject. Not without reason the law uses verbs in the third person singular to determine the specific powers of the authority: «appoints», «coordinates», «manages» and so on. After all, this form makes it possible to most accurately express the «dual» nature of these powers: to indicate the rights of the body, which at the same time can act as its responsibilities.

In the legal encyclopedia, the concept of «powers» is interpreted as a set of rights and responsibilities of state bodies and public organizations, as well as officials and other persons assigned to them in the manner prescribed by law to perform their functions ${ }^{17}$. Holosnichenko D.I. cites the opinion of Professor B. Lazarev, who defines authority as a set of specific rights and responsibilities that are provided for the implementation of the functions assigned to the body. The concepts of «powers» are similar in meaning to the concept of «competence». At the same time, they differ primarily in the completeness of the elements that are part of a phenomenon. Defining these concepts, scientists are not unanimous in their distinction ${ }^{18}$. It is widely believed that the competence of the body is the same powers, but appropriately established for the performance of a particular body.

16 Ткаченко А.О. Поняття компетенції державного органу. Часопис Київського університету права. 2009. № 4. С. 192-197.

${ }_{17}$ Юридична енциклопедія: В 6 т. / Редкол.: Ю.С. Шемшученко (відп. ред.) та ін. Київ: «Укр. енцикл.», 2003. Т. 5: П-С., 736 с.

${ }^{18}$ Голосніченко Д.І. Повноваження та компетенція: спільні риси і відмінності. Правове регулювання суспільних відносин у сфері культури. Сучасний стан та перспективи розвитку: тези Всеукраїнської наук. конф. (Київ, 15 травня 2007 р.). Київ: КНУКІМ, 2007. С. 26-27. 
Competence is a legal reflection (mediation) of the functions assigned to state bodies in special regulations by fixing the goals, objectives and the set of rights and responsibilities necessary for their implementation, i.e. state powers ${ }^{19}$. As a result, we have a proven view that competence is a broader concept and includes in its structure such an element as powers. Together, they constitute the legal status of the authority.

For our further study, we will adhere to the view that the competence of the Accounting Chamber is determined by the object of control and legal relations to the subject of this body and the powers (rights and responsibilities) endowed by the body and its officials to achieve its purpose enshrined in Art. 98 of the Constitution of Ukraine.

The competence of any body depends on the scope of its activities, which is determined by the purpose of its creation. The Accounting Chamber was established and operates in order to control on behalf of the Verkhovna Rada of Ukraine over the receipt of funds in the State Budget of Ukraine and their use. The Law of Ukraine «On the Accounting Chamber» provides a more detailed list of objects and legal relations that fall under the competence of the body and notes that the scope of the law extends to relations arising in connection with the control functions of the Accounting Chamber. This indicates a direct dependence of competence on the functions assigned to the investigated control body. It is the functions that determine one of the elements of competence, namely the objects and legal relations that are characterized by belonging to the subject of the Accounting Chamber. Today, the Accounting Chamber is responsible for external state financial control. The external nature of control, first of all, means disobedience to the executive branch, which is the main factor in the independence of control from the main state administrators and their decisions. The Lima Declaration notes the need for financial independence of the highest financial body, the domestic legislator reflected this, noting that funds for the Accounting Chamber are allocated directly from the State Budget of Ukraine, their amount is set annually by the Verkhovna Rada of Ukraine and indicated in the State Budget ${ }^{20}$.

The objects of control of the Accounting Chamber in the exercise of powers defined by the Law of Ukraine «On the Accounting Chamber» are state bodies, authorities of the Autonomous Republic of Crimea, local

\footnotetext{
19 Голосніченко І.П., Голосніченко Д.І. Теорія повноважень, їх легітимність та врахування потреб і інтересів при встановленні на законодавчому рівні. Вісник НТУУ «КПI». Політологія. Соціологія. Право: збірник наукових працьь. 2011. № 1(9). С. 147-155.

20 Лімська декларація керівних принципів контролю: Міжнародний документ від 01.01.1977. URL: https://zakon.rada.gov.ua/laws/show/604_001\#top.
} 
governments, other budgetary institutions, including foreign diplomatic missions of Ukraine, businesses, public or other organizations, funds of compulsory state social and pension insurance, the National Bank of Ukraine and other financial institutions.

The list of powers for the Accounting Chamber to conduct financial audits and performance audits, examinations, inspections and other forms of activity is enshrined in the relevant law in Art. $7^{21}$.

Art. 110 of the Budget Code stipulates that the powers of the Accounting Chamber include control over the receipt and use of funds of the State Budget of Ukraine, including the formation, servicing and repayment of public debt, efficiency of state budget management, use of local budgets in terms of transfers provided from the state budget, as well as the receipt of national taxes and fees assigned to local budgets or their share and the use of local budgets, which are determined by the functions of the state and transferred to the Autonomous Republic of Crimea and local government ${ }^{22}$.

Following the results of each quarter, the Accounting Chamber submits to the Verkhovna Rada of Ukraine conclusions on the state of implementation of the law on the State Budget of Ukraine, as well as proposals to eliminate violations identified in the reporting budget period.

Based on the above-mentioned, it can be argued that domestic legislation is fully in line with the Lima Declaration, which recommends to provide the control accounting authorities with the broad powers to obtain information. Both the Budget Code of Ukraine and the relevant law provide a fairly detailed list of powers vested in the domestic SAI.

Despite the compliance of domestic legislation with international standards, it is not without its drawbacks. In most countries, SAIs have the power to bring perpetrators to justice, seize control of accounts, accept proposals for the temporary removal or release of violators, and prosecute violators in the event of significant violations of the law ${ }^{23}$. Most domestic scholars and practitioners, in order to increase the efficiency and effectiveness of the Accounting Chamber, place the main emphasis on giving it «punitive» powers. A similar opinion was reached by S.P. Pankiv, who in order to confirms the words of V. Symonenko, noted that «to

${ }^{21}$ Про Рахункову палату: Закон України від 02.07.2015 p. № 576-VIII. URL: https://zakon. rada.gov.ua/laws/card/576-19.

22 Бюджетний кодекс України: Закон України від 08.07.2010 р. № 2456-VI. URL: https://zakon.rada.gov.ua/laws/card/2456-17.

${ }^{23}$ Гавдьо Ю. щодо правового статусу Рахункової палати України з урахуванням зарубіжного досвіду. Юридичний радник. 2005. № 6(8). С. 53-56. 
improve the efficiency of the Accounting Chamber it is necessary ... to some extent solve the problem of response by the management of the audited entities to its official documents, to correct deficiencies, timely take the necessary measures to eliminate them and prevention in the future». It is advisable, in our opinion, to supplement Art. 7 of the Law of Ukraine «On the Accounting Chamber» ${ }^{24}$, the powers that will facilitate the prosecution for non-compliance with the recommendations provided by the audit by the Accounting Chamber.

\section{CONCLUSIONS}

At the stage of its formation and development, financial control was an integral part of state control and was considered as its direct component. With the development of the science of financial law, financial control is considered as an independent area of financial activity of the state and ceases to be identified with the system of regulatory authorities. The influence of financial control by the state necessitates the interaction of all control and financial bodies. The functioning of the financial control system today is inefficient due to the following factors: the lack of a single system of bodies, a single coordination centre, defining the powers and tasks of bodies, and these are just some of the issues that need regulation.

The systematization of public financial control bodies does not provide for rigid vertical subordination of individual elements, in this case, it means the presence of a coordination centre, which will help to improve the system. The body of state financial control is an element of the state mechanism, belonging to a certain organizational structure, which has exclusive powers to control the funds and property of the state in the interests of the latter in order to ensure legality and compliance with financial discipline.

In the best traditions of international practice, SAIs have bodies that carry out external financial control - this means that they are not a part of the organizational structure of the bodies under their control. Given the membership of the Accounting Chamber in INTOSAI since 1998, it has all the features of an SAI that can perform a coordinating function in the financial control system.

Financial control should be considered as a special category of financial law, expressed in legal form and aimed at achieving a certain goal through the implementation of competence. The competence of the Accounting Chamber is a set of powers, expressed in certain rights and responsibilities

\footnotetext{
${ }^{24}$ Паньків С.П. Рахункова палата України у системі державного фінансового контролю.
} Університетські наукові записки. 2005. № 3(15). С. 232-237. 
of its members, in relation to controlled objects in order to control the state budget, which have a normative fixation and non-performance or improper performance of which involves liability. The competence of the Accounting Chamber is determined by the affiliation of the object of control and legal relations to the subject of jurisdiction of the SAI and the powers (rights and responsibilities) vested in the body and its officials to achieve the goal of its creation, enshrined in Art. 98 of the Constitution of Ukraine.

\section{SUMMARY}

The article is devoted to the study of the Accounting Chamber as a leading institution in the financial control activities of the state. Issues related to the origin of financial control and its inseparable connection with state control are revealed. It is proved that despite the large number of bodies exercising financial control, it is impossible to state its effectiveness and efficiency, due to the lack of the normative act, which would define the system of financial control bodies and delimit the competence of such bodies to avoid duplication of powers. The issues of competence and implementation of the powers of the Accounting Chamber as a body of financial control to achieve the goal set by the legislator are considered separately. The categories of «competence» and «powers», their relationship and interdependence in the activities of the body under study were analysed.

\section{REFERENCES}

1. Угода про асоціацію між Україною, 3 однієї сторони, та Свропейським Союзом, Свропейським співтовариством з атомної енергії і їхніми державами-членами, з іншої сторони: Міжнародний документ від 27.06.2014 p. URL : https://zakon.rada.gov.ua/laws/show/984_011\#Text.

2. Андрійко О.Ф. Організаційно-правові проблеми державного контролю у сфері виконавчої влади : автореф. дис. ... д-ра юрид. наук. Київ : I-т. держави і права ім. В.М. Корецького НАН України, 1999. 38 с.

3. Тароєва В.В. Інститути контрольної влади в сучасній Україні : автореф. дис. ... канд. юрид. наук. Одеса, 2010. 21 с.

4. Павлик I. Відмінність понять «державний контроль» $\mathrm{i}$ «державний нагляд»: нормативно-правовий аспект. Науковий віник. 2017. Вип. 20. URL : http://lvivacademy.com/vidavnitstvo_1/visnyk20/fail/Pavlyk.pdf.

5. Андрійко О.Ф. Зазначена праця.

6. Административное право Украины : учебник / Под общей ред. С.В. Кивалова. Харків : «Одиссей», 2004. 880 с.

7. Козырин А.Н. Финансовый контроль. Финансовое право. Москва : Юристь, 1996. 399 с. 
8. Болдырев Ю. Формирование внешнего государственного финансового контроля в РФ: вопросы истории, организации и методологии. Российский экономический журнал. 2007. № 5-6. С. 25-41.

9. Грачева Е.Ю. Налоговое право: вопросы и ответы : учебное пособие / Грачева Е.Ю., Соколова Э.Д. М. : Юриспруденция, 2001. 128 с.

10. Шохин С.О., Воронина Л.И. Бюджетно-финансовый контроль и аудит. Теория и практика применения в России : науч.-метод. пособие. Москва : Финансы и статистика, 1997. 240 с.

11. Горбач М. Про створення єдиної системи державного фінансового контролю в Україні. Право України. 2005. № 10. С. 83-86.

12. Симоненко В.К. Бюджет без контролю - держава без бюджету. Демократична Украӥна. 2002. № 4. С.4.

13. Савченко Л.А. Правові основи фінансового контролю : навч. посіб. Київ : Юрінком Інтер, 2008. 504 с.

14. Фінансове право України : підручник / М.П. Кучерявенко, Д.О. Білінський, О.О. Дмитрик та ін.. ; за ред. д-ра юрид. наук, проф. М.П. Кучерявенка. Харків : Право, 2013. 400 с.

15. Юридична енциклопедія: В 6 т. / Редкол.: Ю.С. Шемшученко (відп. ред.) та ін. Київ : «Укр. енцикл.», 2001. Т. 3: К-М., 792 с.

16. Ткаченко А.О. Поняття компетенції державного органу. Часопис Київського університету права. 2009. № 4. С. 192-197.

17. Юридична енциклопедія: В 6 т. / Редкол.: Ю.С. Шемшученко (відп. ред.) та ін. Київ : «Укр. енцикл.», 2003. Т. 5: П-С., 736 с.

18. Голосніченко Д.І. Повноваження та компетенція: спільні риси і відмінності. Правове регулювання суспільних відносин у сфері культури. Сучасний стан та перспективи розвитку : тези Всеукраїнської наук. конф. (Київ, 15 травня 2007 р.) К. : КНУКІМ, 2007. С. 26-27.

19. Голосніченко І.П., Голосніченко Д.І. Теорія повноважень, їх легітимність та врахування потреб і інтересів при встановленні на законодавчому рівні. Вісник НТУУ «КПІ». Політологія. Соціологія. Право : збірник наукових пращь. 2011. № 1(9). С.147-155.

20. Лімська декларація керівних принципів контролю: Міжнародний документ від 01.01.1977. URL : https://zakon.rada.gov.ua/laws/ show/604_001\#top.

21. Про Рахункову палату : Закон України від 02.07.2015 p. № 576-VIII. URL : https://zakon.rada.gov.ua/laws/card/576-19.

22. Бюджетний кодекс України : Закон України від 08.07.2010 р. № 2456-VI. URL : https://zakon.rada.gov.ua/laws/card/2456-17.

23. Гавдьо Ю. щодо правового статусу Рахункової палати України з урахуванням зарубіжного досвіду. Юридичний радник. 2005. № 6(8). C. 53-56. 
24. Паньків С.П. Рахункова палата України у системі державного фінансового контролю. Університетські наукові записки. 2005. № 3(15). C. 232-237.

25. Койчева О.С. Рахункова палата як суб'єкт фінансового контролю : дис. ... канд. юрид. наук. Одеса, 2016. 237 с.

\section{Information about author:}

Koicheva O. S., $\mathrm{PhD}$ in Law, Associate Professor at the Department of Administrative and Financial Law National University "Odesa Law Academy" 23, Fontanska doroha str., Odesa, 65009, Ukraine 